\title{
Behavioral analysis and productive performance of piglets in the post-weaning phase in enriched environments
}

\section{Análise comportamental e desempenho produtivo dos leitões na fase pós- desmame em ambientes enriquecidos}

Zara Alves Lacerda (D), Cinthia Maria Carlos Pereira (D), Eric Márcio Balbino (D), Camila Meneghetti (D), Lucas Pereira de Souza Silva iD, Tássio Chaves Santos (iD

Department of Agrarian and Environmental Sciences, Universidade Estadual de Santa Cruz (UESC), Ilhéus, BA, Brazil

\begin{abstract}
This study aimed to assess the effect of environmental enrichment on the behavior and productive performance of castrated piglets, both males and females, from 21 to 35 days of age. For this, 45 animals were randomly distributed in three treatments (control, environmental enrichment with pet bottle, and suspended rope), five replicates, and three animals per experimental unit. The experiment lasted 14 days, with 30 minutes of daily observation, and the observations were performed by the focal animal and behavior relative sampling. The data were recorded about the interactions with the objects, stereotypes, social and agonistic interactions, and animal activities. The productive performance was assessed by weighing three animals of the experimental unit, and their feed at the beginning and at the end of the experiment. We evaluated the daily weight gain, daily feed intake, and feed conversion. A descriptive analysis of the behavioral data was performed. The
\end{abstract}

* Corresponding author: cmcpereira@uesc.br

Received: 2018 Sep 10 | Approved: 2019 May 6 performance data were evaluated by analysis of variance. The comparison between the treatments was performed by Tukey test at 5\% probability. Animals that received either the pet bottle or the suspended rope did not show a significant difference in social, agonistic, and physiologist interactions, but the results showed a significant difference in ludic interactions. Animals that did not receive any environmental enrichment displayed higher rates of stereotypes and aggressive behaviors. There was no effect $(p>0.05)$ of the treatments on the daily weight gain, daily feed intake, and feed conversion. Environmental enrichment improves the welfare of piglets by increasing physiological, social, and playful behaviors (positive), and decreasing stereotypy and agonistic behaviors (negative), but it does not influence the productive performance of animals.

Kewyords: Ethology. Stress. Swine. Welfare 


\section{Resumo}

Objetivou-se com este trabalho avaliar o efeito do enriquecimento ambiental sobre o comportamento $e$ desempenho produtivo de leitões castrados, de ambos os sexos, com idade entre 21 e 35 dias. Para isso, foram utilizados 45 animais distribuídos em blocos casualizados com três tratamentos (tratamento controle, enriquecimento ambiental com garrafa pet, e enriquecimento com corda suspensa), cinco repetições e três animais por unidade experimental. 0 experimento teve duração de 14 dias, com registro de 30 minutos diários por baia, e as observações foram realizadas por animal focal e amostragem relativa ao registro. Os dados foram registrados em relação às interações com os objetos, estereotipias, interações sociais e agonistas, $e$ atividades dos animais. Para avaliar o desempenho produtivo, todos os animais de cada unidade experimentale a ração foram pesados no início e no final do experimento para determinar o ganho de peso diário, consumo de ração diário e conversão alimentar. Foi realizada uma análise descritiva dos dados de comportamento, os dados de desempenho produtivo foram avaliados por análise de variância $e$ a comparação entre os tratamentos foi realizada por Teste de Tukey a 5\% de probabilidade. Os tratamentos garrafa pet e corda suspensa não tiveram diferença significativa nas interações sociais, agnósticas e fisiológicas, mas os resultados demonstraram diferença significativa nas interações lúdicas. Foram observadas maiores taxas de estereotipias e interações agressivas dos animais no tratamento sem enriquecimento ambiental. Não houve efeito $(p>0,05)$ dos tratamentos sobre o ganho de peso diário, consumo de ração diário e conversão alimentar. $O$ enriquecimento ambiental melhora o bem-estar dos leitões, aumentando os comportamentos fisiológico, social e lúdico (positivos) e diminuindo estereotipia e agressividade (negativos), porém não influencia o desempenho produtivo dos animais.

Palavras-chave: Etologia. Estresse. Suínos. Bem-estar.

\section{Introduction}

Brazil has the fourth largest production and exportation of pork meat in the world (ABPA, 2016). These results were possible due to improvements over the last years in the entire swine production chain, such as genetics, nutrition, environment, management, and sanity. The Brazilian pig production consists of the intensive confinement system to optimize the use of the facilities and the management of the animals, and to obtain better economic and productive performance (Baptista et al., 2011). However, this production system is under debate since it can generate severe environmental pollution and does not prioritize the animals' quality of life (Vasconcelos et al., 2015). Production systems can directly affect the natural behavior of this species, because it provides an environment with different stress situations, poor social interaction, high density of animals, lack of freedom to express natural behavior, and low air quality in the facilities (Maia et al., 2013).

The requirement of the consumer market for the improvement of animal welfare during breeding fostered the development of researches in this area (Verbeke and Vackier, 2004). Animal welfare is a state of harmony between the animal and its environment, with optimal physical and physiological conditions, and high quality of life (Hurnik, 1992). The lack of species-specific behaviors generally are suggestive of weak environmental enrichment (van de Weerd and Day, 2009).

One way to improve animal welfare in the current pig farming system without drastically affecting production costs is to use environmental enrichment. The term "enrichment" implies improvements of different natures: physical, social, with food, among others, applied to positively change the environment (Newberry, 1995). The post-weaning period is a critical stage for the piglets due to the change of environment, separation from the female, and change of the feeding from liquid to solid. In such a critic period, environmental enrichment can contribute to providing an environment more suited to the behavioral needs of piglets (Ferreira et al., 2001).

Environmental enrichment in pens may use several kinds of objects, such as straw, wood, hay, sawdust, suspended objects (tires and chains) and others that do not affect animal health. The European Union have been nominating suitable materials for enrichment activities since 2008 (The Council of the European Union, 2009). The use of proper chewing and digging objects may improve the activity of the animals, resulting in a reduction of stereotyped behaviors. 
Given the above, the aim of this study was to evaluate the effect of two types of environmental enrichment on the behavior and productive performance of piglets in post-weaning.

\section{Material and methods}

The research was performed in a commercial farmlocated in Itabuna town, BA. Forty-five castrated males and females piglets from 21 to 35 days of age (post-weaning phase) were used in a randomized block experimental design with three treatments (control treatment - TC: no environmental enrichment; environmental enrichment with pet bottle - PET; and environmental enrichment with suspended rope - ROPE), five replicates, and three animals per experimental unit. The study was approved by the Ethics Committee in Animals Use of UniversidadeEstadual de Santa Cruz (CEUAUESC), protocol 003/16.

On the first day of the experiment, all animals were weighed, identified with a marker stick for individual classification (red, green, and blue) and distributed in raised cages with a removable floor, containing manual feeders and plastic nipples. The thermal variations inside the shed were registered daily at $4 \mathrm{pm}$ using an analog thermometer, TM38CAP model from Equitherm. The animals received a commercial feed, balanced according to the nutritional requirements of each stage of the piglets, that contained in their composition: corn, soybean meal, and supplementation of a commercial nucleus. Feed and water were provided ad libitum during the test period. Cages were cleaned, and feeds leftovers were collected daily.

Behavioral observations were performed daily from $8 \mathrm{am}$ to $12 \mathrm{am}$ and $1 \mathrm{pm}$ to $4 \mathrm{pm}$ with focal animal method (Gonçalves et al., 2014). After seven days of experiment, the toys were renewed. For the behavior observations with piglets, ethogram description was adapted based on Nannoni et al. (2016) (Table 1). The behaviors evaluated were: interactions with the objects (to measure the frequency, duration, and latency), social interactions, aggressive interactions, stereotypes, and animal activities. The behavioral parameters were measured by frequency of replications per treatment; then, they were transformed in percentage with standard deviation. The average duration of play behavior with enrichment objects was also calculated in seconds.

To evaluate the productive performance, all animals, feed and feed leftovers were weighed at the beginning and at the end of the experiment to determine daily weight gain, daily feed intake and feed conversion.

Table 1 - Ethogram - Piglets behavioral repertoire

\begin{tabular}{|c|c|c|}
\hline Parameters & & Description \\
\hline \multirow{6}{*}{$\begin{array}{l}\text { Physiological } \\
\text { activities }\end{array}$} & Inactive & $\begin{array}{l}\text { The animal is laying down (lateral or } \\
\text { ventral) with closed eyes and without } \\
\text { oral activity }\end{array}$ \\
\hline & Active & $\begin{array}{l}\text { The animal is woken up and in alert } \\
\text { state: stands up, lies down or sits down } \\
\text { with open eyes }\end{array}$ \\
\hline & Sniff & $\begin{array}{l}\text { The animal sniffs the floor, in circular } \\
\text { motions }\end{array}$ \\
\hline & Drink & $\begin{array}{l}\text { The animal consumes water in the } \\
\text { nipple }\end{array}$ \\
\hline & Eat & The animal is feeding in the stable \\
\hline & Scratch & The animal scratch on some object \\
\hline \multirow{3}{*}{ Stereotypies } & Lick & The animal licks the floor without food \\
\hline & Bite & $\begin{array}{l}\text { The animal bites the penfences or } \\
\text { nipple }\end{array}$ \\
\hline & Tweak & $\begin{array}{l}\text { The animal tweaks the feeder or floor } \\
\text { without food }\end{array}$ \\
\hline \multirow{3}{*}{$\begin{array}{l}\text { Social } \\
\text { interactions }\end{array}$} & Nibble & $\begin{array}{l}\text { The animal performs chewing move- } \\
\text { ments while touching with the mouth } \\
\text { another pig }\end{array}$ \\
\hline & Smell & $\begin{array}{l}\text { The animal smells other pig, in circular } \\
\text { motions }\end{array}$ \\
\hline & Lick & The animal licks other pig \\
\hline \multirow{3}{*}{$\begin{array}{l}\text { Agonistic } \\
\text { interactions }\end{array}$} & Push & $\begin{array}{l}\text { The animal pushes other pig with the } \\
\text { head }\end{array}$ \\
\hline & Bite & The animal bites other pigs \\
\hline & Fight & $\begin{array}{l}\text { The animal is struggling with another } \\
\text { pig by quick movements with the head }\end{array}$ \\
\hline \multirow{2}{*}{$\begin{array}{l}\text { Playful } \\
\text { interactions }\end{array}$} & Object & $\begin{array}{l}\text { The animal bites, sniffs or pushes the } \\
\text { object (enrichment) }\end{array}$ \\
\hline & $\begin{array}{l}\text { Without } \\
\text { object }\end{array}$ & $\begin{array}{l}\text { The animal leans another pig, runs } \\
\text { alone or with other pigs in the area }\end{array}$ \\
\hline
\end{tabular}

Note: Adapted from Nannoni et al. (2016). 


\section{Statistic analyses}

The behavioral and productive performance data were evaluated by analysis of variance and with the treatment's comparison performed by the Tukey test. All analyses were performed using the Sisvar program (Ferreira, 2011) at 5\% probability.

\section{Results and discussion}

The average maximum and minimal temperatures recorded at the farm during the experiment were, respectively, $34.3 \pm 1.36{ }^{\circ} \mathrm{C}$ and $25.8 \pm 3.62{ }^{\circ} \mathrm{C}$.

Animals that did not receive enrichments displayed higher degrees of activity (eating, drinking, active, inactive, smelling, and scratching activities) than those that received one of the enrichments provided $(\mathrm{p}=0.06)$ (Table 2), having as a contributing factor the increase in inactive behavior, which corroborates with the study by Casal-Plana et al. (2017), that is justified by the redirection of the behavior when one does not have an environment with enrichment.

During the experiment, inactivity behavior was prevalent in all treatments (Table 2). This observation is consistent with Broom and Fraser (2010), who explained that inactivity-related activities are essential for the species due to this evolutionary characteristic, since free-range animals that remained immobile for a longer time were less likely to be detected by the predators, besides conserving energy and making possible the repair of the synapses of the nervous system. Thus, leisure is characterized as a natural behavior of pigs and it is not associated with weak environmental enrichment.

Table 2 - Quantitative analysis of the number of behavior repetitions in 7 hours/cage of piglets, from 21 to 35 days of age, kept in an environment with or without environmental enrichments (times of repetitions)

\begin{tabular}{lcccc}
\hline Parameters & Control & Bottle & Rope & P.value \\
\hline Activities & $274.0 \pm 27.2$ & $223.4 \pm 44.4$ & $272.8 \pm 28.4$ & 0.0615 \\
Stereotypies & $16.8 \pm 8.5$ & $10.6 \pm 0.9$ & $16.0 \pm 9.4$ & 0.3769 \\
Social interactions & $7.2 \pm 5.2$ & $7.2 \pm 5.6$ & $6.0 \pm 3.2$ & 0.9009 \\
Agonistic interactions & $10.0 \pm 9.1$ & $5.2 \pm 4.5$ & $4.8 \pm 3.6$ & 0.3722 \\
Playful interactions & $2.2 \pm 1.0$ & $10.8 \pm 6.3$ & $16.8 \pm 10.3$ & 0.0131 \\
\hline
\end{tabular}

The treatments did not show differences in stereotypic behaviors. However, stereotypies were observed in all treatments. Stereotypies are sequences of relatively invariant behaviors, frequently repeated, and considered without abnormal function (Odberg, 1978). Examples of stereotypical behaviors may be: licking the floor, biting the railing, and digging the floor of the cage. This fact can be explained by the post-weaning stress that the animals suffered and by the absence of strategies that can alleviate it (Lingling et al., 2012).

As comparing the behaviours of the animals that received enrichment objects, we could observe that there was an indirect correlation between the interactions with the objects and stereotypies.
In animals belonging to the control group, this comparison could not be performed. From this observation, we can infer that the control group did not display any reduction in social interaction because of the lack of enrichment objects toward which they could redirect their behaviors.

Social and agonistic behaviors did not display significative differences in frequency among the treatments (Table 2). These results diverge from those presented by Melotti et al. (2011), who observed that piglets had lower rates of aggression and spent less time fighting after environmental enrichment with substrates such as hay. We observed higher degrees of social and agonistic interaction among animals that received the suspended rope, than 
among those that received the plastic bottle (2.33 and 3.23 , respectively), or those that did receive no enrichment at all (1.89 and 1.50, respectively).

A higher number of aggressive interactions (average between the treatments: 2.25) were expected in all groups due to the stress that the piglets suffer at this stage because of the infantmother separation, change of environment and idleness (Lingling et al., 2018). Aggressive interactions are social behaviors that are crucial to create a hierarchy among the piglets. However, the intensification of these behaviors may indicate stress and lack or poor enrichment in the pen, triggering further abnormal behaviors such as aggressions that can lead to cannibalism and selfmutilation, affecting the performance of these animals (van de Weerd and Day, 2009).

The animals that had suspended rope as environmental enrichment presented higher rates $(p=0.01)$ of play behavior between them or with the objects provided in the pen (Table 2). This result corroborates with the study of Trickett et al. (2009), that evaluated the interaction of post-weaning piglets with two types of objects, suspended rope and wood block, and observed that the animals had more interaction with the suspended rope.

The use of pet bottles and suspended rope as environmental enrichment increased the rate of positive behaviors (play) when compared to the control group, corroborating with the results obtained by Casal-Plana et al. (2017).

The total duration of the interactions and play with the objects did not differ between the bottle and suspended rope treatments. This result disagrees to those reported by Trickett et al. (2009), who observed that animals interacted for a longer time with the suspended rope compared with the bottle. Horback et al. (2016) observed that flexible, destructible and hygienic materials, such as rope, shown a higher interaction preference compared to non-hygienic materials among finishing pigs. We can infer, therefore, that as pet bottles are loose on the floor of the bay, they get dirty and kneaded rapidly, resulting in the loss of interest by the animals.

In the present study, the interest of the piglet toward both toys, the suspended rope, and the pet bottle was higher during the first two days of exposure, as long as the toys were still clean (Guy et al., 2002). As refers to the pet bottle, the animals lost interest as the toy became dirty and used up. The animals had more interest in the suspended rope during the first two days. During the following days of exposition to the objects, their interest was lower and constant.

In the second time contact, when the toy was substituted by a new and equal one, there was an increase in the interest similar to the first time. Trickett et al. (2009), evaluating the continuous exposure of piglets to suspended rope, observed that piglets were more interested in the suspended rope in the first and third week of exposure, when a new object was provided, but the interaction was lower in the third week when compared with the first one, demonstrating the importance of different objects.

Production performance of piglets did not differ significantly among the three groups of piglets included in this study (Table 3). Although the behavior of the animals was different between the treatments, it was not enough to alter the productive performance. Tricket et al. (2009) also observed no difference in the performance of post-weaning piglets exposed to suspended rope and wood block, probably due to the lack of interest of the animals after the first two days in the first and third week, with an absence of significant difference in the productive performance between the treatments with and without environmental enrichment. In our opinion, to obtain better results, it is necessary to change the toys every two or three days.

Table 3 - Productive performance of piglets, from 21 to 35 days of age, with and without environmental enrichment

\begin{tabular}{lccccc}
\hline Parameters & \multicolumn{5}{c}{ Treatment } \\
\cline { 2 - 6 } & Control & Bottle & Rope & CV \% & P value \\
\hline IW (kg) & 7.748 & 7.730 & 7.782 & 1.06 & 0.6150 \\
FW (kg) & 12.310 & 12.320 & 12.130 & 4.64 & 0.8414 \\
DFC (kg & 0.428 & 0.450 & 0.422 & 11.58 & 0.6640 \\
DAWG (kg) & 0.322 & 0.324 & 0.306 & 13.01 & 0.7588 \\
FC (kg/kg) & 1.290 & 1.310 & 1.310 & 6.20 & 0.9187 \\
\hline
\end{tabular}

Note: $\mathrm{CV}=$ coefficient of variation. $\mathrm{IW}=$ initial weight; $\mathrm{FW}=$ final weight; DFC = daily feed consumption; $D A W G$ = daily average weight gain; $F C=$ food conversion. ANOVA followed by Tukey test $5 \%$. 


\section{Conclusion}

Environmental enrichment with suspended rope improves animal welfare. However, none of the objects used in this study affected the productive performance of piglets.

\section{Acknowledgments}

The authors acknowledge the Universidade Estadual de Santa Cruz and the Swine Farm for enabling and permitting the execution of this project, and all the employees and colleagues for the support.

\section{References}

ABPA - Brazilian Animal Protein Association. Annual Report 2016 [cited 2018 May 5]. Available from: https:// tinyurl.com/y3f383st.

Baptista RIAA, Bertani GR, Barbosa CN. Indicadores do bem-estar em suínos. Cienc Rural. 2011;41(10):182330.

Broom DM, Fraser AF. Comportamento e bem-estar de animais domésticos. São Paulo: Manole; 2010. 452 p.

Casal-Plana N, Manteca X, Dalmau A, Fàbrega E. Influence of enrichment material and herbal compounds in the behavior and performance of growing pigs. Appl Anim Behav Sci. 2017;195:38-43.

Ferreira DF. Sisvar: A computer statistical analysis system. Cienc Agrotec. 2001;35(6):1039-42.

Ferreira VPA, Ferreira AS, Donzele JL, Albino LFT, Gomes PC, Cecon PR, et al. Dietas para leitões em aleitamento e pós-desmame. Rev Bras Zootec. 2001;30(3):753-60.

Gonçalves TM, Bastos R, Soares RTN, Torres DS. Indicadores comportamentais na avaliação do bemestar de matrizes de suínos alojadas em baias individuais e piquetes coletivos. J Bras Ciecn Anim. 2014;7(14): 523-40.
Guy JH, Rowlinson P, Chadwick JP, Ellis M. Behaviour of two genotypes of growing-finishing pigs in three different housing systems. Appl Anim Behav Sci. 2002;75(3):193-206.

Horback KM, Pierdon MK, Parsons TD. Behavioral preference for different enrichment objects in a commercial sow herd. Appl Anim Behav Sci. 2016;184:7-15.

Hurnik JF. Behaviour. In: Phillips C, Piggins D (Eds.). Farm animals and the environment. Wallingford: $C A B$ International; 1992. p. 235-44.

Lingling F, Bo Z, Huizhi L, Schinckel AP, Tingting L, Qingpo $\mathrm{C}$, et al. Teeth clipping, tail docking and toy enrichment affect physiological indicators, behavior and lesions of weaned pigs after re-location and mixing. Livest Sci. 2018;212:137-42.

Maia APA, Sarubbi J, Medeiros BBL, Moura DJ. Enriquecimento ambiental como medida para o bemestar positivo de suínos (Revisão). Rev Eletronica Gest Educ Tecnol Ambient. 2013;14(14):2862-77.

Melotti L, Oostindjer M, Bolhuis JE, Held S, Mendl M. Coping personality type and environmental enrichment affect aggression at weaning in pigs. Appl Anim Behav Sci. 2011;133(3-4):144-53.

Nannoni E, Sardi L, Vitali M, Trevisi E, Ferrari A, Barone $F$, et al. Effects of different enrichment devices on some welfare indicators of pos-weaned undocked piglets. Appl Anim Behav Sci. 2016;184:25-34.

Newberry RC. Environmenal enrichment: increasing the biological relevance of captive environments. Appl Anim Behav Sci. 1995;44(2-4):229-43.

Odberg FO. Abnormal behaviours: stereotypies. Proceedings of the First World Congress on Ethology Applied to Zootecnics. Madrid; 1978. p. 475-80.

The Council of the European Union. Council Directive 2008/120/EC of 18 December 2008 laying down minimum standards for the protection of pigs. Official Journal of the European Union; 2009 [cited 29 jan 2019]. Available from: https://tinyurl.com/y4kns95x. 
Trickett SL, Guy JH, Edwards SA. The role of novelty in environmental enrichment for the weaned pig. Appl Anim Behav Sci. 2009;116(1):45-51.

van de Weerd HA, Day JEL. A review of environmental enrichment for pigs housed in intensive housing systems. Appl Anim Behav Sci. 2009;116(1):1-20.
Vasconcelos EKF, Borges LS, Silva AL, Andrade TV, Santos ET, Sousa Jr SC, et al. Comportamento de suínos na fase de crescimento criados em ambiente enriquecido. J Anim Behav Biometeorol. 2015;3(4):120-3.

Verbeke W, Vackier I. Profile and effects of consumer involvement in fresh meat. Meat Sci. 2004;67(1):159-68. 